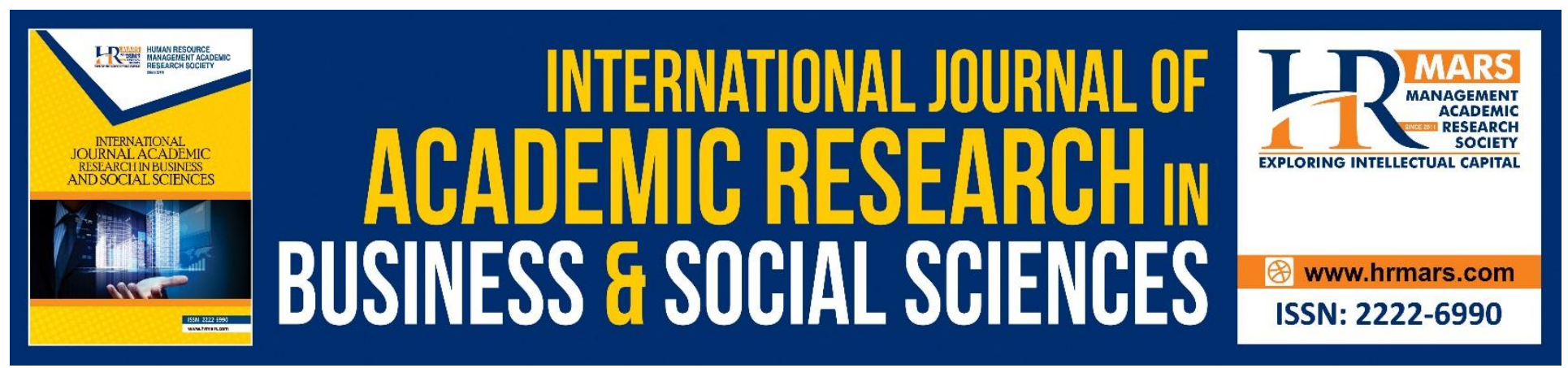

\title{
Customer Purchase Intention on Online Grocery Shopping
}

Tan Pei Kian, Alvin Chin Wai Loong and Stany Wee Lian Fong

To Link this Article: http://dx.doi.org/10.6007/IJARBSS/v8-i12/5260 DOI: 10.6007/IJARBSS/v8-i12/5260

Received: 21 Oct 2018, Revised: 29 Dec 2018, Accepted: 04 Jan 2019

Published Online: 09 Jan 2019

In-Text Citation: (Kian, Loong, \& Fong, 2018)

To Cite this Article: Kian, T. P., Loong, A. C. W., \& Fong, S. W. L. (2018). Customer Purchase Intention on Online Grocery Shopping. International Journal of Academic Research in Business and Social Sciences, 8(12), 15791595.

Copyright: (c) 2018 The Author(s)

Published by Human Resource Management Academic Research Society (www.hrmars.com)

This article is published under the Creative Commons Attribution (CC BY 4.0) license. Anyone may reproduce, distribute, translate and create derivative works of this article (for both commercial and non-commercial purposes), subject to full attribution to the original publication and authors. The full terms of this license may be seen at: $\underline{\text { http://creativecommons.org/licences/by/4.0/legalcode }}$

\section{Vol. 8, No. 12, 2018, Pg. 1579 - 1595}

Full Terms \& Conditions of access and use can be found at http://hrmars.com/index.php/pages/detail/publication-ethics 


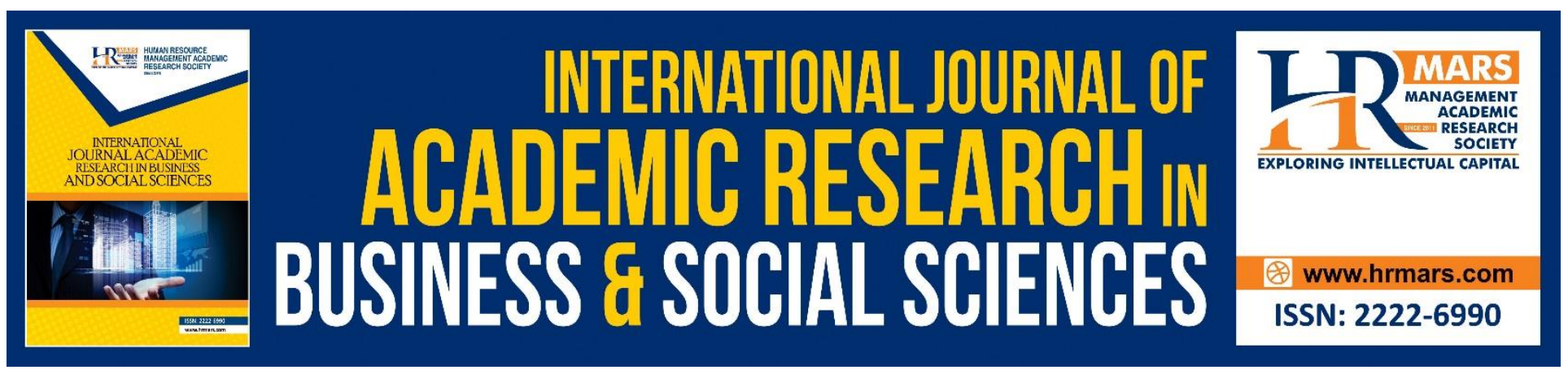

\title{
Customer Purchase Intention on Online Grocery Shopping
}

\author{
Tan Pei Kian, Alvin Chin Wai Loong and Stany Wee Lian Fong \\ Multimedia University, Malacca, Malaysia
}

\begin{abstract}
The internet has been progressively used to encourage online business transactions between entities and customers for different products and services. One of the applications that have gotten much consideration over the most recent couple of years is online grocery shopping (OGS). Grocery shopping is a piece of vital undertakings that must be completed with a specific end goal to satisfy the requirements for household or notwithstanding for individual consumption. The rise of online grocery shopping is all around adjusted by the greater part of the developed countries, particularly in America and European market. In any case, this situation is rarely occurring in Malaysia. These days, the accessibility of technologies has supported the utilization of online platform, for example, online grocery shopping. The Technology Acceptance Model (TAM) is utilized to give the theoretical foundation for this study. In view of the empirical data gathered from the study, the findings show the strength of the TAM model in investigating the customer purchase intention on online grocery shopping in Melaka. What's more, the visibility of OGS was additionally observed to be a vital element for its acknowledgement by the community. The motivation behind this study is to comprehend the factors that will influence the customer purchase intention on online grocery shopping in Melaka. The five independent variables that will be analysed in this study are perceived usefulness, perceived ease of use, perceived risk, visibility and social influence. There are 155 questionnaires has been distributed and only 150 questionnaires have been collected. Perceived ease of use found to be not significant and social influence is identified as the most important factor which influences consumer purchase intention on online grocery shopping in Melaka.
\end{abstract}

Keywords: Purchase Intention, Online Grocery Shopping, Online Purchase, E-Commerce

\section{Introduction}

The internet has opened a window of chance to nearly anybody in view of its capacity to make feasible and direct of business via internet, or by interfacing individuals worldwide without geological limitations. Shoppers can place any order for merchandises and services basically anyplace and anytime without facing any hassle (Li \& Gery, 2000; Waldo, 2000). The internet likewise has gives new chances to advertisers to offer creative approach to market, convey and disseminate merchandise 
and information to their targeted shoppers. The "internet" can be characterized as a cooperation of more than a huge number of interconnected networks. In particularly, the internet is a set of computer network from all around the world that are connected together for trading of information, distributing and processing of task through ordinary phrase and procedures (Fatin, 2015).

Hypermarket is one of the examples which is framed and carried into the market with the assistance of the quick technological headway. A developing number of retailers move their consideration regarding developing economics as a result the pattern of retailing store changed. WalMart, Tesco and Costco are some of worldwide retailers which appear to be extremely well known among purchasers. Retailing by means of internet is a standout amongst the most quickly developing type of trade in today's developed world. Internet has built a closer relationship between the retailers and the purchasers everywhere throughout the world and vice versa. The impact of the websites on the retail sector has been a great deal more exceptional than most of different business division. As a result, it creates a new retail format known as electronic retailing or e-tailing. Online shopping has been a specific cause of excitement and attentions for shoppers to look into due to the fast-paced technological growth. Grocery shopping has been viewed as distressing and as a chore. Notwithstanding, buyers' uptake of online grocery shopping has been slower than foreseen.

One of the reasons for the low uptake seems to be the delivery fee (Huang \& Oppewal, 2006). Delivery charge is one of the conceivable reasons why most shoppers are still hesitant about online grocery shopping. Other concerns which highlighted are including privacy and security (Zaini et al., 2011). The average online shopping shows a higher rate if compares to the online grocery shopping. At the end of the day, more numerous customers do have web based shopping background with different items. Consumers would prefer to walk-in to the physical traditional and modern supermarket to purchase groceries even though the existing e-grocers and traditional grocers do provide electronic grocery shopping. Sadly, taking a gander at the present circumstance, many of us can assume that purchaser's inclination of purchasing groceries through online in Malaysia is not broadly utilized. The research found that buyers might doubt about the conditions of the groceries while doing grocery shopping online (Huang \& Oppewal, 2006). Evidently, contrasted with physical grocery shopping, the accessibility of information and review from past shoppers empower shopper to know better about the conditions of the groceries. Regardless, there are as yet few of research that are focused on taking a gander at online and offline purchase behaviour especially in term of its acknowledgement and expectation to utilize it later on. The available current specific issues focus on brand loyalty, brand names and general clients' acknowledgment on the pros and cons of online grocery (Nadia et al., 2016). Besides that, academically, there is scholarly insightful research here. As a result of the absence of available data, there is a recognizable nonappearance of distributed exact work on what sorts of purchasers in a behavioural perspective are mindful to shopping on the web versus in an ordinary store (Andrew et.al, 2004).

Regardless, the benefits of online grocery shopping do not show up addressing everyone as a total substitution to their routines to the supermarket. In the year 2000, out of 4.5 million families that acquired merchandise on the web, only 1.1 million did thusly more than once every month. The number of internet users has expanded up to 100,103 since 1997 if compares only 90 internet users in 1992 (Nadia et al., 2016). Even though the number of internet users has increased, however the usage of web based grocery remains low. Therefore, this development of the internet should enhance 
the whole idea of purchasing groceries online in Malaysia. In spite of the fact that online users are expanding much of the time, online shoppers are not expanding the same number of as users expanding. As time goes by, the consumers" convictions to online shopping is expanding, however how much their awareness on online shopping still should be explored. Therefore, in this study the aim is to fill up the gaps and investigate the factors that influence customer purchase intention on online grocery shopping in Malacca. The fundamental goal of this review is to investigate the factors that influence consumer purchase intention on online grocery shopping in Malacca. Hence, the research objectives are stated as below:

RO1: To examine the relationship between perceived usefulness and customer purchase intention on online grocery shopping in Malacca.

RO2: To investigate the relationship between perceived ease of use and customer purchase intention on online grocery shopping in Malacca.

RO3: To determine the relationship between perceived risk and customer purchase intention on online grocery shopping in Malacca.

RO4: To examine the relationship between visibility and customer purchase intention on online grocery shopping in Malacca.

RO5: To investigate the relationship between social influence and customer purchase intention on online grocery shopping in Malacca.

\section{Literature Review}

In this globalization period, e-commerce owns possibility improvement in late quite a while and along these lines various great retailers are searching for worldwide infiltration and development particularly through web based business. It might have been due to web based business will be much simpler and speedier methodologies with augment business in the simplicity approach. It also provides for possibilities with overall businessmen to fabricate their labels and figure out around the clients in distinctive nations before extending their business or setting an association or retail outlet particularly nations. Malaysian government had put some efforts in order to propel internet utilization in whole nation, for example, such as setting up 1Malaysia internet centre (MCMC, 2013). It revealed that those governing bodies' arrangements to extend the usage for internet in order to enhance the reading and writing proficiency rates among the citizens same time by suggestion assistance that web based shopping programmes in Malaysia. Malaysia has finished fast change in the assignment of broadband services inside limited timeframe duration that family broadband infiltration rate increased by $20.7 \%$ since 2006 to 2009 outperforming those focus from claiming $50 \%$ infiltration rate aimed in year 2010 (MCMC, 2012). The expansion in the broadband utilization amid the Malaysians to certain degree could distort web based shopping bargains. Malaysia situated best 30th of the 2013 Global Retail E-Commerce Index among various nations with the web based market appeal score of 36.8 motivations behind the general web based market estimate, purchaser conduct, advancement potential and framework (Hana et al., 2013). This worthy index could be a direct result of the government attempts to propel online business among Malaysians.

The estimate improvement in online business is a direct result of a speedy upturn in the amount of PCS in Malaysia, and advancement in the degree of PCs connected to the internet 
consistently. This gives more noticeable opportunities to Malaysians to lead both business and shop on the web (Legard, 1998). According to International Data Corporation (IDC), it is imperative for the close-by associations in Malaysia to have an average comprehension of the commercial centre for their items and their potential clients before involving in web based business (Louis \& Leon, 1999). With an average appreciation of their potential clients, online retailers and agents can develop all the more intense and concentrated on online retail operations that meet the requirements and wants of their online clients (Shannon, 1997). This is essential in order to ensure powerful use of their web based retailing business in Malaysia. On account of the current financial crisis, regardless, this survey discovered that more customers from all levels are starting to purchase groceries through online websites for the foreseeing advantages. In addition, the KPMG International (2012) examines that PDA and tablets are chosen as the preferable devices to shop online. Along these lines, the proceeded with movement of compact applications and its broadened comfort of utilization and related services should raise widely more on the event of online grocery shopping. Furthermore, the said investigate legitimizes that web based grocery stores propose the latest products, cash and on-budget customers a way to deal with helpfully seek and procure items, adjacent by given the possibility of all the more monitor control of their budgetary arrangement and almost check their cart contents (KPMG International, 2012). Ensuing to considering each one of the points of view, one of the basic motivations for online buyers is the shopping convenience (Joana, 2013). The review performed by Rohm and Swaminatham (2004) clarifies that convenience and variety are the basic concealed drivers in the web based channel, though time savings and recreational shopping introductions have a tendency to be the primary inspiration in the offline store format. Although online shopping saves time but delivery waiting time could be the gap between the purchase and actual acquisition of products.

The idea of web based grocery shopping begun in Malaysia in the mid-2000, spearheaded by humble name, for example, PasarBorong Online (Zaini et al., 2011). Be that as it may, either the online grocery merchants' plans of action does not work or they are not profiting mainly due to less exposure about those organizations' presence and execution. Euromonitor International in its current report dated April 2014 has achieved 13.5\% in the esteem development of grocery category in 2013. For the present, these online retailers convey lasting through the year over the Klang Valley utilizing an armada of vehicles. This district was picked that it has the most imperative rate of participates related with the Internet and computer literacy in Malaysia (Singh, 2011). Eventually, notwithstanding the way that there are couple of online food merchants players in Malaysia, none is outstanding as none of them produces any imperative sales figures in year 2010 (Euromonitor International, 2011). In any case, April 2013 has meant the establishment of web based retailing by Tesco Stores (Malaysia) Sdn Bhd. It was furthermore point by point that the nearby online grocery merchants are predicted to confront some trying conditions at the short gauge time frame. The wait-and-see approach is considered depending on the accomplishment of Tesco. Different factors that withdraw the consumers' readiness to utilize web based purchase are preferable to choose the products themselves and offline stores' existing promotions. Therefore, online grocery shopping tends to be more appealing mainly to the youthful and well informed purchasers who lean toward convenience. In any case, this will remain an extra to the nation's grocery business since web based shopping for food is still new in Malaysia (Euromonitor International, 2014). 


\section{Purchase Intention}

Behavioural intention (BI) is characterized as a customer's intention to subscribe or to buy an item later on. Furthermore, it is a sort of purchase intention which can be utilized to anticipate purchaser's buying patterns. Intention is also characterized as the view of a person towards performance of a particular behaviour (Piyanath \& Suthawan, 2013). Based on the previous research, Kurnia and Chien (2003) were using the term of behavioural intention which indicates the same meaning with purchase intention. Purchase intention is to some degree decision or individual intend to pick regardless of whether he or she needs to buy a particular thing (Ooi, 2014). Purchase intention is moreover considered as a buyer's intention or plan to purchase a thing. Purchase intention can in like manner be described as the capacity of a customer to purchase thing. As indicated by Hsin Kung et al. (2013), purchase intention is one of the fundamental elements to foresee customer buying pattern. Purchase intention can be measured by the amount of customers buying a product and customer loyalty. Also, purchase intention is the time when a purchaser has a proposed arrange or has a good recognition towards a thing. The development in purchase intention will incite to more customers on their readiness to purchase a thing. Two conditions must be met in order to fulfil the intention to predict behaviour (Anna et. al, 2015). Firstly, the measure of behaviour has to be made after the intention as intentions can change periodically. Secondly, the respondents have to be conscious in order to make choice or decision, for example, online grocery shopping decision making. As demonstrated by Ajzen (2002) intentions are viewed as being related to the immediate behaviour. It is said that a purchaser frequently expects to act if the feelings about the action is surveyed positively and supported by the general population in their environment. The statement above shows uplifting attitudes and solid subjective norms affect purchaser intention.

\section{Perceived Usefulness}

Perceived usefulness (PU) is portrayed as how much a subject assumed that utilizing a specific framework would improve his or her occupation execution according to Davis (1989). TAM said that "usefulness" is affected by "ease of use", on the grounds that the less requesting an innovation is to use, the more accommodating it can be (Piyanath \& Suthawan, 2013). As per the exploration of Monsuwe and Ruyter (2004), they found that "usefulness" alludes to customers' recognition that utilizing the Internet as a shopping medium gives better shopping experience and that recognition impact buyers' attitude toward online shopping and their intention to shop online. Perceived usefulness is the essential for mass market innovation acknowledgment, which relies on upon shoppers' assumptions about how innovation can enhance and rearrange their lives (Piyanath \& Suthawan, 2013). A website is considered useful if it can perform the task according the clients' needs. The usefulness and exactness of the website likewise impact client's attitude. Clients may keep utilizing an e-commerce service benefit on the off chance that they think of it as helpful, paying little mind to the likelihood that they may be disillusioned with their earlier use (Bhattacherjee, 2001a). Buyers likely assess and consider item related data before buy, and perceived usefulness in this way might be more vital than the shopping experience. What's more, perceived usefulness predicts IT usage and intention to utilize (Adam et al.1992), including the utilizing of online business. 


\section{Perceived Ease of Use}

Davis (1989) depicted perceived ease of use as how much a buyer accepts by utilizing a specific innovation, the purchaser would be free from exertion. Davis (1989) additionally characterized ease as "opportunity from trouble or awesome exertion". Raman (2011) expressed that exertion is an effort of physical or mental quality to play out an action. Besides, Sulistiyaningsih et al. (2014) translated perceived ease of use as for what degree in which the customer saw the development as something simple to use. Perceived ease of use is exceptionally mainstream in new innovation adoption studies (Phang, 2016). Lee and Park expressed that on account of web based shopping condition, the perceived ease of use alludes to the website's simplicity of route. The review by Park (2009) on comprehension college students' behavioural intention to utilize online learning characterized perceived ease of use as the degree to which the pupils accept there is almost no or no psychological exertion expected to utilize the online learning system. Henceforth, the perceived ease of use in this exploration alludes to the grocery clients' convictions that utilizing the online grocery platform requires negligible exertion. Mohd et al. (2011) specified that perceived ease of use can affect perceived usefulness and both the factors are distinct dimensions. Park (2009), inferred that the self-efficacy of the innovation firmly influences the perceived ease of use of the buyers both previously, then after the fact utilizing the innovation. In any case, Park presumed that the innovation's self-efficacy indirectly affects the buyers' intention to utilize the innovation through perceived ease of use. Then again, Lin and Lu (2000) announced that greater view of ease of use is advanced by the data openness of the innovation. On the off chance that potential clients assume that a specific innovation is helpful, they may likewise trust that the innovation is not that difficult to utilize (Davis,1989).

\section{Perceived Risk}

Perceived risk is expressed as the instability of conceivable negative results utilizing an item or services (Featherman \& Pavlou, 2002). Gronhaug and Stone (1995) expressed that the idea of perceived risk was presented by Raymond A. Bauer in 1960. Knight (1921) characterized quantifiable uncertainty to be a hazard. On top of that, Gronhaugh and Stone (1995) additionally clarified that hazard or instability are identified with the situation of decision, whereby an individual should settle on a choice. At whatever time customers consider making a buy, they will confront an arrangement of uncertainty about the item or administrations and this is alluded to as perceived risk (Dontigney, 2016). Limayem et al. (n.d.) clarified that perceived risk alludes to the shoppers' view of vulnerability and outcomes of buying an item. The decision of conduct depends on the particular outcomes come about because of an activity. As such, perceived risk is the potential for misfortune in acquiring the coveted after effect of utilizing a framework (Featherman \& Pavlou, 2002). According to Osman et al. (2010), there are two central classifications of perceived risk amid the online shopping process. The primary classification is connected with the item and organizations, utilitarian misfortune, time misfortune, product peril, opportunity loss and cash related misfortune. The second associated with privacy peril, security and status of the structure. Dogtigney (2016) recommended that there are six types of perceived risk that every business needs to go up against, to be particular functional risk, social risk, budgetary risk, physical risk, time risk and psychological risk. Featherman and Pavlou (2002) summed up the two imperative classes of perceived risk into execution and psychosocial. 
Execution is down and out into financial matters, temporal and effort while psychosocial is divided into psychological and social. The examination done by Osman et al. (2010) construed that perceived risk can be decreased with higher confidence in the shop. The higher confidence would then have the capacity to make a more inspirational disposition in picking a specific shop. The research by Limayem et al. (n.d.) likewise found that perceived results influence the buyers' attitude and intention to buy an item. This implies an individual may not redo the same choice if that individual sees negative outcomes or hazard. Featherman and Pavlou (2002) expressed that purchasers show a hesitance to make online transaction for the most part because of perceived risk. More or less, numerous sorts of writing bolster the use of risk factors to comprehend the buyers' activity.

\section{Visibility}

Retailer visibility reveals a particular level of data about a retailer (Luo et.al, 2012). Precisely, online visibility reflects the combined impacts of last promoting plan and projects (Drèze \& Zufryden 2004). Customers able to influence presumptions regarding merchants' capacity and unwavering quality in perspective of their apparent advertising use (Kirmani \& Rao 2000). Therefore, a web based retailer with high visibility is presumably going to be known as proficient, valid and reliable as holding high visibility requires high expenses. Furthermore, such a huge venture makes it costly as it adds advantage to the retailer. Also, retailer visibility chooses how unmistakable a buyer is with the businessman. The all the greater outstanding a buyer is with a web based retailer; the less psychological distance there is between the client and the businessman. Things that are psychological distance (products, incidents) are those that are absent in the quick experience of reality (Liberman et al. 2007). In their examination of psychological distance between the web based retailers and buyers, Edwards et al. (2010) communicated that psychological distance occurs in the web based business condition. Buyers' impression of psychological distance is most wonderful with a businessman of low visibility, as they have a tendency to recognize less about its quality. Separation and influence are frequently inseparably associated. Psychological closeness gives consciousness that is certifiable, more veritable, more open, and more reliable, while distance is regularly associated with uneasiness in web based shopping. The positive effects caused by closeness lead to a higher customer satisfaction based on the affective response-satisfaction perspective. Shoppers surely have a tendency to stay away from risk and show inclinations for well-known products rather than unknown products (Bornstein, 1989). Therefore, low visibility will give negative impacts to retailers.

\section{Social Influence}

Subjective norm insinuates the buyers' acknowledgment that people that important to them think a particular lead should be performed or not (Raman, 2011). Mohd et al. (2011) portrayed subjective norm as the customers' feelings that a particular individual or social occasion endorse or oppose the direct of the customers. Most tend to play out a specific direct with feelings that it would make positive results. Thusly, the subjective norm will provoke the use of the actual framework. In this investigation, the effect of the subjective norm was surveyed in social influence. Davis (1989) emphasized on the significance of social influence in innovation acknowledgment. Social influence alludes to the perceived social pressure conveys a specific conduct (Park, 2009). Wang and Chou (2014) described social influence as how the overall public around can impact a man's decisions 
making. They found that social influence is related to external factors, to be particular partners, relatives and colleagues. They additionally expand that social influence incorporates the degree to which informal organizations can influence individuals' conduct by utilizing messages and signals. It assumes a critical part in comprehension, clarifying and foreseeing the use of the new innovation and the acceptance behaviour (Malhotra \& Galletta, 1999). Mohd et al. (2011) prescribed that attitude changes at different kind of "levels". These levels of changes by then happen contrasting with the various strategies whereby the purchasers recognize the effects. Malhotra and Galletta (1999) recognized three diverse social influence forms in influencing the buyer's conduct. The first is compliance - when shoppers embrace the conduct with the desire to maintain a strategic distance from misfortune or pick up motivations, not for the confidence in its substance. The second procedure is identification - when customers acknowledge the influence exclusively because of the reason to make or keep up an association with a specific person or gathering. Last but not least is internationalization - when the buyers recognize the impact since it suits their esteem frameworks. Malhotra and Galletta (1999) also illuminated that the social influence forms assistance decides the customers' obligations or psychological attachment to utilise the new development.

\section{Methodology}

Figure 1 shows the research framework of this study. Perceived usefulness, perceived ease of use, perceived risk, visibility and social influence are used in this analysis to establish the relationship with customer purchase intention towards online grocery shopping. Based on the Figure 1, the conceptual framework of factors influencing customer purchase intention towards online grocery shopping in Malacca is shown. Five hypotheses were generated as below:

$\mathrm{H} 1$ : There is a significant relationship between perceived usefulness and customer purchase intention on online grocery shopping in Malacca.

$\mathrm{H}$ 2: There is a significant relationship between perceived ease of use and customer purchase intention on online grocery shopping in Malacca.

$\mathrm{H} 3$ : There is a significant relationship between perceived risk and customer purchase intention on online grocery shopping in Malacca.

$\mathrm{H} 4$ : There is a significant relationship between visibility and customer purchase intention on online grocery shopping in Malacca.

H5: There is a significant relationship between social influence and customer purchase intention on online grocery shopping in Malacca. 
INTERNATIONAL JOURNAL OF ACADEMIC RESEARCH IN BUSINESS AND SOCIAL SCIENCES Vol. 8, No. 12, Dec, 2018, E-ISSN: 2222-6990 @ 2018 HRMARS

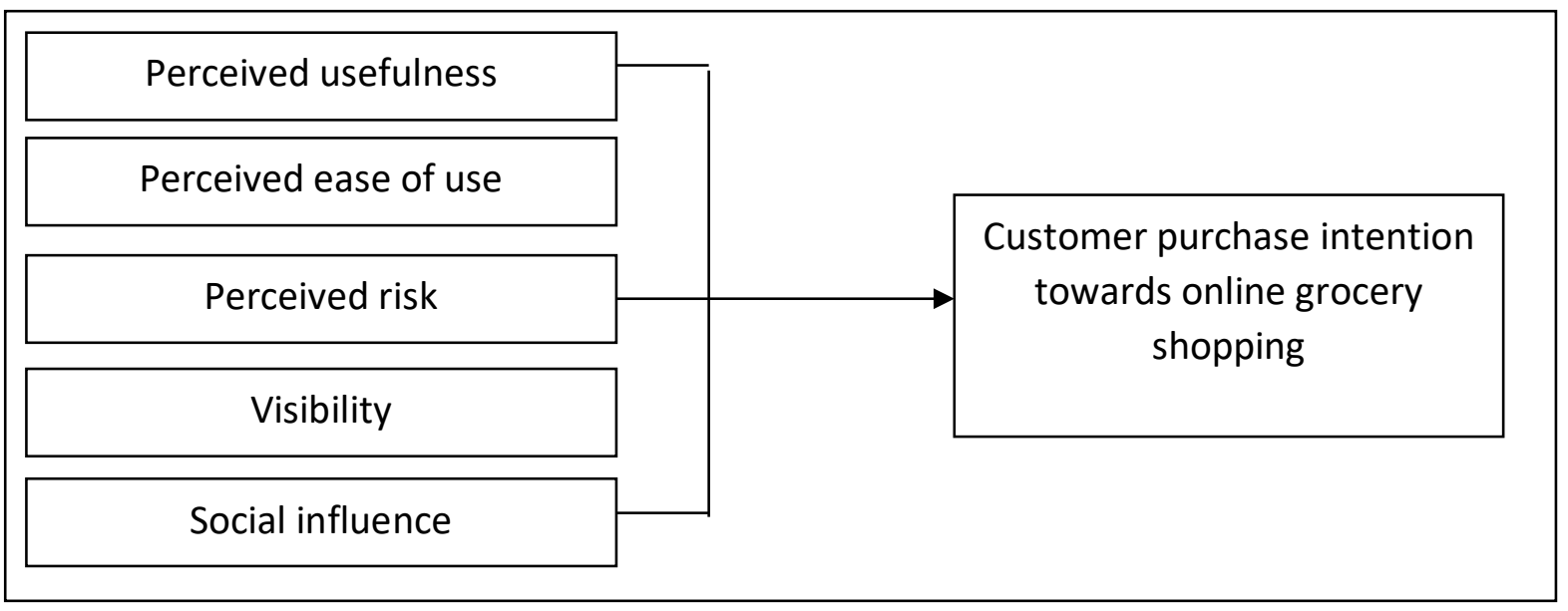

Figure 1 Research framework

This study covers the distribution of questionnaires, collection of data, analyses of data and reporting of the final result and findings. The study setting in this study is not-contrived as this study is a correlation study, which takes place in a natural environment. The collection of data is conducted face to face which empowers the analyst to request favours from the conceivable respondents partake in noting the questionnaires. In this research, there were total of 155 questionnaires been distributed and only 150 questionnaires have been collected. The questionnaire items of all variables were adopted from one study written by Kurnia and Chien (2003). The data that were collected from the completed questionnaire which will be analysed by using the SPSS software in order to achieve the objective. By using the SPSS software, descriptive analysis, reliability analysis, and multiple linear regression will be tested.

\section{Results \& Discussion}

Assessment of Reliability

Table 1: Summary of reliability test

\begin{tabular}{|l|c|c|}
\hline \multicolumn{1}{|c|}{ Constructs } & Cronbach's alpha & N of items \\
\hline Perceived usefulness & 0.976 & 8 \\
\hline Perceived ease of use & 0.993 & 4 \\
\hline Perceived risk & 0.955 & 4 \\
\hline Visibility & 0.995 & 3 \\
\hline Social influence & 0.941 & 3 \\
\hline Customer purchase intention & 0.865 & 4 \\
\hline
\end{tabular}

Table 1 demonstrates the Cronbach's alpha value for each of the variables in this study. According to Table 1, the construct which has the most noteworthy Cronbach's alpha value is visibility, 0.995 and the most minimal Cronbach's alpha value is customer purchase intention, 0.865 . Table 1 concludes that all listed variables are reliable and stable as Hair et al. (2006) explains the minimum requirement of cronbach's alpha value is at least 0.7. 
INTERNATIONAL JOURNAL OF ACADEMIC RESEARCH IN BUSINESS AND SOCIAL SCIENCES

Vol. 8, No. 12, Dec, 2018, E-ISSN: $2222-6990$ C 2018 HRMARS

The Profile of Respondents

Table 2: Demographic Profiles

\begin{tabular}{|c|c|c|c|}
\hline Variables & Category & Frequency & Percentage \\
\hline \multirow[t]{2}{*}{ Gender } & Male & 70 & $46.67 \%$ \\
\hline & Female & 80 & $53.33 \%$ \\
\hline \multirow[t]{5}{*}{ Age } & $<20$ & 21 & $14 \%$ \\
\hline & $20-30$ & 50 & $33.33 \%$ \\
\hline & $31-40$ & 51 & $34 \%$ \\
\hline & $41-50$ & 26 & $17.34 \%$ \\
\hline & $>50$ & 2 & $1.33 \%$ \\
\hline \multirow{5}{*}{$\begin{array}{l}\text { Highest level of } \\
\text { education }\end{array}$} & High school & 49 & $32.7 \%$ \\
\hline & Diploma & 20 & $13.3 \%$ \\
\hline & Bachelor degree & 60 & $40 \%$ \\
\hline & Masters & 16 & $10.7 \%$ \\
\hline & $\mathrm{PhD}$ & 5 & $3.3 \%$ \\
\hline \multirow{6}{*}{$\begin{array}{l}\text { Monthly income } \\
\text { (RM) }\end{array}$} & $<1000$ & 48 & $32 \%$ \\
\hline & $1001-2000$ & 10 & $6.7 \%$ \\
\hline & $2001-3000$ & 62 & $41.3 \%$ \\
\hline & $3001-4000$ & 20 & $13.3 \%$ \\
\hline & $4001-5000$ & 10 & $6.7 \%$ \\
\hline & Total & 150 & $100 \%$ \\
\hline
\end{tabular}

Based on Table 2, out of the 150 respondents, $46.7 \%$ (70 respondents) are male and the remaining $53.3 \%$ ( 80 respondents) are female. Table 2 clarifies the most of respondents are from the age of 31 to 40 years old (34.0\%) and the least respondents are from the age of more than 50 years old (1.3\%). Majority of the respondents are bachelor degree holders (40.0\%) and the least of respondents are PhD holders (3.3\%). Last but not least, in Table 2, most of the respondents earns between RM2001 to RM3000 (41.3\%) and the least of respondents earns between RM 1001 to RM2000 (6.7\%) and RM4001 to RM5000 (6.7\%). 
INTERNATIONAL JOURNAL OF ACADEMIC RESEARCH IN BUSINESS AND SOCIAL SCIENCES

Vol. 8, No. 12, Dec, 2018, E-ISSN: 2222-6990 C 2018 HRMARS

\section{General Questions}

Table 3: General questions on online grocery shopping

\begin{tabular}{|c|c|c|c|}
\hline General questions & Category & Frequency & Percentage \\
\hline \multirow{3}{*}{$\begin{array}{l}\text { Have you ever heard } \\
\text { of online grocery } \\
\text { shopping? }\end{array}$} & Yes, I have. & 62 & $41.3 \%$ \\
\hline & No, I haven't. & 88 & $58.7 \%$ \\
\hline & Total & 150 & $100.0 \%$ \\
\hline \multirow{3}{*}{$\begin{array}{l}\text { Have you ever tried } \\
\text { online } \quad \text { grocery } \\
\text { shopping? }\end{array}$} & Yes, I have. & 0 & $0.0 \%$ \\
\hline & No, I haven't. & 150 & $100.0 \%$ \\
\hline & Total & 150 & $100.0 \%$ \\
\hline \multirow{6}{*}{$\begin{array}{l}\text { If you never had } \\
\text { online } \quad \text { grocery } \\
\text { shopping, please } \\
\text { specify the reason. }\end{array}$} & $\begin{array}{l}\text { I do not know about online grocery } \\
\text { shopping. }\end{array}$ & 75 & $50.0 \%$ \\
\hline & Risk of credit card transactions. & 23 & $15.3 \%$ \\
\hline & Internet illiteracy. & 17 & $11.3 \%$ \\
\hline & Risk of identity theft. & 22 & $14.7 \%$ \\
\hline & Others. & 13 & $8.7 \%$ \\
\hline & Total & 150 & $100.0 \%$ \\
\hline \multirow{3}{*}{$\begin{array}{lr}\text { Do you think that } \\
\text { online } & \text { grocery } \\
\text { shopping } & \text { is } \\
\text { beneficial? } & \end{array}$} & Yes, I do. & 71 & $47.3 \%$ \\
\hline & No, I don't. & 79 & $52.7 \%$ \\
\hline & Total & 150 & $100.0 \%$ \\
\hline \multirow{7}{*}{$\begin{array}{l}\text { If yes, why do you } \\
\text { think online grocery } \\
\text { shopping } \\
\text { beneficial? }\end{array}$} & Easy to order. & 11 & $15.5 \%$ \\
\hline & Variety at one shop. & 14 & $19.7 \%$ \\
\hline & Discounts and offers. & 12 & $16.9 \%$ \\
\hline & Saves time. & 22 & $31.0 \%$ \\
\hline & Avoids long queues. & 12 & $16.9 \%$ \\
\hline & Others. & 0 & 0 \\
\hline & Total & 71 & $100.0 \%$ \\
\hline
\end{tabular}

Table 3 shows that $41.3 \%$ (62 respondents) heard of online grocery shopping and the remaining $58.7 \%$ (88 respondents) do not have any clue about purchasing groceries online. The research found out that all (150 respondents) have not tried online grocery shopping before. All respondents do not apply online grocery shopping in their life mainly because of few reasons. In Table 3, 50\% of the respondents do not know about the online grocery shopping followed by $30 \%$ of the respondents do concern about the risks of identity theft and credit card transactions. $11 \%$ of the respondents have issue on internet illiteracy and the remaining $9 \%$ of the respondents have other reasons which are not listed in the questionnaire. Based on the Table 3, 47\% of the respondents do agree that online grocery shopping is beneficial whereas the remaining $53 \%$ of the respondents do not agree that online grocery shopping is beneficial. Out of the 150 respondents, $47 \%$ of them do agree that online grocery shopping is beneficial. There are few factors that influence their thoughts on the benefits of online grocery shopping. Table 3 tells that 31\% of them do think that online grocery shopping does not require a lot of time consuming. Moreover, $20 \%$ of these respondents do think that online grocery shopping does offer variety of products in one place. $34 \%$ of them believed that they able to skip the 
INTERNATIONAL JOURNAL OF ACADEMIC RESEARCH IN BUSINESS AND SOCIAL SCIENCES

Vol. 8, No. 12, Dec, 2018, E-ISSN: 2222-6990 C 2018 HRMARS

queue congestion and enjoy the discounts and offers at the same time. Lastly, $15 \%$ of these respondents do agree that online grocery shopping is accessible.

\section{Hypothesis Testing}

Table 4: Summary of Multiple Linear Regression

\begin{tabular}{|c|l|c|c|c|}
\hline Ha & \multicolumn{1}{|c|}{ Variable } & \multicolumn{3}{|c|}{ Dependent - Customer Purchase Intention } \\
\cline { 3 - 5 } & & $\begin{array}{c}\text { Standardized } \\
\text { Beta }\end{array}$ & Sig. & Finding \\
\hline$H 1$ & Perceived usefulness & 0.209 & 0.037 & Supported \\
\hline$H 2$ & Perceived ease of use & 0.006 & 0.952 & Not Supported \\
\hline H3 & Perceived risk & 0.158 & 0.038 & Supported \\
\hline H4 & Visibility & 0.205 & 0.003 & Supported \\
\hline H5 & Social influence & 0.427 & 0.000 & Supported \\
\hline
\end{tabular}

Note: Significant at 0.05 level

According to Table 4, all constructs have significant value less than 0.05 except perceived ease of use (0.952). Table 4 explains that all independent variables (perceived usefulness, perceived risk, visibility and social influence) have significant relationship with the dependent variable (customer purchase intention) except perceived ease of use. Social influence is identified as the most important factor which influences consumer purchase intention on online grocery shopping with the highest coefficient beta, 0.427 .

\section{Conclusion}

This research investigates the direct and indirect effects of perceived usefulness, perceived ease of use, perceived risk, visibility and social influence on online grocery shopping in Malacca. According to the findings, perceived usefulness, perceived risk, visibility and social influence have relationship with the customer purchase intention on online grocery shopping in Malacca. The relationship between perceived ease of use and customer purchase intention on online grocery shopping is not supported as reflected in the study. This research is an eye opening to tell that there is a high potential on online grocery shopping to grow in Malaysia. More researches are encouraged to be conducted in other regions of Malaysia to study closer about the online grocery shopping patterns. Therefore, this research will enhance the writing on new innovation or framework appropriation which utilizes the Technology Acceptance Model (TAM).

Perceived ease of use has no relation with customer purchase intention in this research explains that Malaccans prefer to go to the offline stores to shop for their item physically. They find that using the application is tedious and requires a lot of efforts to understand every step in the application to purchase groceries online. TAM model is commonly used to analysis on online shopping. In this research, TAM model is tested on web based grocery shopping to see whether it gives the same result with the generic web based shopping. However, the result showed that only perceived usefulness is significant with the customer purchase intention. One important consideration should be taken if to purchase groceries online is the freshness of the product. 
Consequently, shopping groceries online is much tedious if compares to shop ordinary stuff. The awareness of web based groceries is weak among the Malaccans. Thus, they are sceptical and have no confident in using the application. They are not well educated by the responsible parties on the benefits of the applications including safety. All they look for is time saving and convenience. Malaccans are collectivistic. Word of mouth communication is commonly used among family, friends and co-workers in the Malaccan society. Therefore, information on good deals is easily shared. Confidence level will increase on the application if it is often mentioned in their daily conservation.

\section{Acknowledgement}

Special thanks to Multimedia University for the support and encouragement to conduct this study.

\section{Corresponding Author}

Tan Pei Kian; Multimedia University, Malacca, Malaysia; pktan@mmu.edu.my; Jalan Ayer Keroh Lama, 75450 Melaka Malaysia.

\section{References}

- $\quad$ Adams, D., Nelson, R. \& Todd, P. (1992). Perceived Usefulness, Ease of Use and Usage of Information Technology: A Replication. MIS Quarterly, 16 (2), 227 - 47.

- $\quad$ Ajzen, I. (2002). Perceived Behavioral Control, Self-Efficacy, Locas of Control and the Theory of Planned Behavior. Journal of Applied Social Psychology, 32 (4), 665 - 683.

- $\quad$ Andrews, R.L. \& Currim, I.S. (2004). Behavioural Difference between Consumers Attracted to Shopping Online versus Traditional Supermarkets: Implications for Enterprise Design and Marketing Strategy. International Journal of Internet Marketing and Advertising, 1 (1), $38-61$.

- $\quad$ Anna, Frida \& Louise. (2015). Consumer Attitudes Towards Online Grocery Shopping A Research Conducted on Swedish Consumers. Retrieved from http://www.divaportal.org/smash/get/diva2:812884/FULLTEXT01.pdf.

- $\quad$ Bhattacherjee, A. (2001). An Empirical Analysis of the Antecendents of Electronic Commerce Service Continuance, Decision Support Systems, 32 (2), $201-214$.

- $\quad$ Bornstein, R.F. (1989). Exposure and Affect: Overview and Meta - Analysis of Research, 1968 1987. Psychological Bulletin, 106, 265 - 289.

- Davis, F.D. (1989). Perceived Usefulness, Perceived Ease of Use \& User Acceptance of Information Technology. MIS Quarterly, 13 (3), 319 - 340.

- Dongtigney, E. (2016). Types of Perceived Risk. Retrieved from http://smallbusiness.chron.com/types-perceived-risk-71594.html.

- $\quad$ Dreze, X., \& Zufryden, F. (2004). Measurement of Online Visibility and Its Impact on Internet Traffic. Journal of Interactive Marketing, 18 (1), $20-37$.

- $\quad$ Edwards, J.B., McKinnon, A.C. \& Cullinance, S.L. (2010). Comparative Analysis of the Carbon Foodprints of Conventional and Online Retailing, A Last Mile perspective. International Journal of Psysical Distribution \& Logistics Management, 40 (1/2), 103 - 123.

- $\quad$ Euromonitor International. (2011). Internet Retailing in Malaysia. Country Report. Retrieved from http:www.euromonitor.com/malaysia. 
- Euromonitor International. (April 2014). Internet Retailing in Malaysia. Country Report. Retrieved from http:www.euromonitor.com/malaysia.

- Fatin (2015). Factors that Influencing Consumer Purcahsing Behaviour Among Youth's Generation in Malacca. Retrieved from http://eprints.utem.edu.my.

- $\quad$ Featherman, M.S. \& Pavlou, P.A. (2009). Predicting E-Services Adoption: A Perceived Risk facets Perspective. Human - Computer Interaction Studies in MIS, 1034 - 1046.

- $\quad$ Gronhaug, K. \& Stone, R.N. (1995). Why Perceived Risk Failed to Achieve Middle Range Theory Status: A Retrospective Research Note. European Advances in Consumer Research, 2, 412-417.

- $\quad$ Hair, Jr., J.F., Black, W.C., Babin, B.J., Anderson, R.E., \& Tatham, R. (2006). Multivariant Data Analysis. New Jersey: Pearson International Edition.

- $\quad$ Hana, B.S., Mike, M. \& Parvaneh, N. (2013). The 2013 Global Retail E-Commerce Index: Online Retail is Front and Center in the Quest for Growth. New York: ATKearney.

- Huang, Y. \& Oppewal, H. Why consumers hesitate to shop online: An experimental choice analysis of grocery shopping and the role of delivery fees. International Journal of Retail \& Distribution Management, 34 (4/5), 334-353.

- $\quad$ Kirmani, A. \& Rao, A. R. (2000). No Pain, No Gain: A Critical Review of the Literature on Gignaling Unobservable Product Quality. Journal of Marketing, 64 (2), $66-80$.

- $\quad$ KPMG International (2012), Issues Monitor: Sharing knowledge on topical issues in the Retail industry, $\quad 12, \quad 015 \quad$ - $\quad 012, \quad$ [online]. Available: http://www.kpmg.com/Ca/en/IssuesAndInsights/ArticlesPublications/Documents/issuesmonitor-retail-september-2012.pdf.

- $\quad$ Kurnia, S. \& Chien, A.J. (2003). The Acceptace of Online Grocery Shopping, 219 - 233.

- $\quad$ Legard, D. (1998). E-Commerce Boom Ahead for Malaysia. Computer World Hong Kong, April 3, 1998, p.3.

- $\quad$ Liberman, N., Trope, Y., \& Stephan, E. (2007). Psychological Distance. In A.W. Kruglanski, \& E.T.Higgins (Eds), Social psycology: Handbook of basic principles. New York: Guilford Press.

- $\quad$ Li, Z.G \& Gery, N. (2000). E-Tailing - for All Products. Business Horizons, November-December, $43(6), 49-54$.

- $\quad$ Lim, H., Widdows, R. \& Hooker, N.H. (2009). Web Content Analusis of E-Grocery Retailers: A Longitudinal Study. International Journal of Retail and Distribution Management, 37 (10), 839851.

- $\quad$ Limayem, M., Cheung, C.M. \& Chan, G.W. (nd). A Meta - Analysis of Online Consumer Behavior Empirical Research.

- $\quad$ Lin, J. C., \& Lu, H. (2000). Towards an understanding of the behavioral intention to use a Web Site. International Journal of Information Management, 20, 197-208.

- Luo, Ba \& Zhang. (2012). The Effectiveness of Online Shopping Characteristics and Well Designed Websites on Satisfaction. MIS Quarterly, 36 (4).

- $\quad$ Louis, C. \& Leon, M.L. (1999). Computimes: Evolving with E-Commerce.

- Malaysian Communications and Multimedia Commission. (2012). Annual Report 2012. Cyberjaya: Malaysian Communications and Multimedia Commission. 
INTERNATIONAL JOURNAL OF ACADEMIC RESEARCH IN BUSINESS AND SOCIAL SCIENCES

Vol. 8, No. 12, Dec, 2018, E-ISSN: 2222-6990 @ 2018 HRMARS

- Malaysian Communications and Multimedia Commission. (2013). Communications \& Multimedia: Pocket Book of Statistics. Cyberjaya: Malaysian Communications and Multimedia Commission.

- $\quad$ Malhotra, Y. \& Galleta, D.F. (1999). Extending the Technology Acceptace Model to Account for Social Influence: Theoretical Bases and Empirical Validation, 1 - 13.

- $\quad$ Mohd, F., Ahmad, F., Samsudin, N., \& Sudin, S. (2011). Extending the Technology Acceptamce Model to Account for Social Influence, Trust and Integration for Pervasive Computing Environment: A Case Study in University Industry, American Journal of Economics and Business Administration, 3 (3), $552-559$.

- $\quad$ Monsuwe, T.P., Dellaert, B.G.C. \& Ruyter, K. (2004). What Drives Consumers to Shop Online? A Literature Review. International Journal of Service Industry Management, 15 (1), $102-121$.

- $\quad$ Nadia, N.S., N.M., \& W.E. (2016). The Acceptace and the Intention of Online Groceries Shopping in Malaysia. Journal of Applied Environmental and Biological Sciences, 6 (6), 29 - 34.

- $\quad$ Ooi. (2014). Factors Influencing Purcahse Intention Towards Organic Food.

- $\quad$ Osman, S., Yin-Fah, B.C \& Choo, B. H. (2010). Undergraduates and Online Purchasing Behavior. Asian Social Science, 6(10), $133-146$.

- $\quad$ Park, S.Y. (2009). An Analysis of the Technology Acceptamce Model in Understanding University Students' Behavioral Intention to Use E-Learning. Educational Technology \& Society, 12 (3), 150 $-162$.

- Phang. (2016). Consumers Acceptance Towards E-Grocery. Retrieved from http://eprints.utar.edu.my.

- $\quad$ Piyanath \& Suthawan. (2013). Factors Affecting Behavioural Intention to Purchase Low-Cost Airline E-Ticket in Thailand. International Journal of Business and Economics.

- Premalatha (2014, March 7). Tesco to expland online shopping service. TheSundaydaily. Retrieved from http://thesundaily.my/news/978139.

- $\quad$ Raman, A. (2011). The Usage of Technology Among Education Stdents in University Utara Malaysia: An Application of Extended Technology Acceptance Model. International Journal of Education and Development using Information and Communication Technology, 7 (3), 4 - 17.

- $\quad$ Rohm, A.J. \& Swaminathan, V. (2004). A Typology of Online Shoppers based on Shopping Motivation, Journal of Business Research, 57, $748-757$.

- $\quad$ Shannon, J. (1997). Sales Boost for Retainers on Net. Marketing Week London, December 11, 1997, p.17

- $\quad$ Singh, K. (2011, February 7). Investing Big in Online Groceries. The Edge Malaysia, pp. 3.

- $\quad$ Sulistiyaningsih. M., Tamnotoh, J.J., \& Tanaamah, A.R. (2014). Technology Acceptance Model and Online Learning Media: An Empirical Study of Online Learning Application In a Provate Indonesian University. Journal of Theoretical and Applied Information Technology, 69 (1), 136 $-144$.

- Waldo, B.H. (2000). Redefining the Health Care Landscape with the Internet.

- Wang, E.S. \& Chou, N.P. (2014). Consumer Characteristics, Social Influence and System Factors on Online Group Buying Repurchasing Intention, 15 (2), 119 - 134.

- $\quad$ Zaini, Z.M., Ramli, N., Abd. Ghani, F., Samsudin, A., Hamid, M., Jusoff, K., Ngali, N., Rahmat, N., Khalid, K. \& Musa, M. (2011). Online Grocery Shopping: The Effect of Time Availability on 
INTERNATIONAL JOURNAL OF ACADEMIC RESEARCH IN BUSINESS AND SOCIAL SCIENCES

Vol. 8, No. 12, Dec, 2018, E-ISSN: 2222-6990 @ 2018 HRMARS

Malaysian Consumer Preferences. World Applied Sciences Journa 12 (Special Issue on Service Sector Tansforms the Economy), $60-67$. 